\title{
Effect of sources and split application of phosphorus on dry matter accumulation, nutrients uptake and soil properties under partially reclaimed salt affected soil
}

\section{K. K. VERMA, SURESH KUMAR, VIJAY KUMAR AND SUNIL KUMAR}

Received : 06.01.2016; Revised : 27.03.2016; Accepted : 23.04.2016

MEMBERS OF RESEARCH FORUM:
Corresponding author :
K. K. VERMA, Department of Soil
Science, Narendra Deva University
of Agriculture and Technology,
Kumarganj, FAIZABAD (U.P.) INDIA

Co-authors :

SURESH KUMAR, VIJAY KUMAR AND SUNIL KUMAR, Department of Soil Science, Narendra Deva University of Agriculture and Technology, Kumarganj, FAIZABAD (U.P.) INDIA

\section{Summary}

A field experiment was conducted at Instructional Farm of Narendra Deva University of Agriculture and Technology, Kumarganj, Faizabad during Kharif season 2012 to evaluate the effect of sources and split application of phosphorus on dry matter accumulation, nutrients uptake and soil properties under partially reclaimed salt affected soil. The experiment comprised of seven treatments i.e. $\left(\mathrm{T}_{1}\right)$ control, $\left(\mathrm{T}_{2}\right) 60 \mathrm{kgP}_{2} \mathrm{O}_{5}$ ha $^{-1}$ basal through DAP, $\left(\mathrm{T}_{3}\right) 45 \mathrm{~kg}$ basal $+15 \mathrm{~kg} \mathrm{P}_{2} \mathrm{O}_{5}$ ha $^{-1}$ at tillering through DAP, $\left(\mathrm{T}_{4}\right) 30 \mathrm{~kg}$ basal $+15 \mathrm{~kg} \mathrm{P}_{2} \mathrm{O}_{5} \mathrm{ha}^{-1}$ through DAP, $\left(\mathrm{T}_{5}\right)$ $60 \mathrm{~kg} \mathrm{P}_{2} \mathrm{O}_{5}$ ha $^{-1}$ basal through SSP, $\left(\mathrm{T}_{6}\right) 45 \mathrm{~kg}$ basal $+15 \mathrm{~kg} \mathrm{P}_{2} \mathrm{O}_{5}$ ha $^{-1}$ in Randomized Block Design replicated thrice. The rice variety NDR-359 was taken as test crop. Among sources of phosphatic fertilizer viz., single super phosphate and diammonium phosphate, single superphosphate were found more effective over diammonium phosphate with respect of dry matter accumulation, phosphorus uptake, $\mathrm{EC}, \mathrm{pH}, \mathrm{OC}$ and available nitrogen, phosphorus and potassium in soil.

Key words : Rice, SSP, DAP, Split application, Partially reclaimed salt affected soil

How to cite this article : Verma, K.K., Kumar, Suresh, Kumar, Vijay and Kumar, Sunil (2016). Effect of sources and split application of phosphorus on dry matter accumulation, nutrients uptake and soil properties under partially reclaimed salt affected soil. Asian J. Soil Sci., 11 (1) : 86-89 : DOI : 10.15740/ HAS/AJSS/11.1/86-89. 